\title{
Export Margins, Price and Quantity of Belarus's Export Growth
}

\author{
Shavkat Otamurodov, Shujin Zhu, Ihtisham ul Haq, Tenglong \\ Zhong $^{1}$
}

\begin{abstract}
This paper examines the sources of Belarus's export growth and decomposes export growth into extensive and intensive margins. This study also aims to determine export margins for intermediate and final goods and to determine the price and quantity components of the intensive export margin. In order to achieve the desired objectives, we use two methods for decomposing export growth, the count method and the export shares method. We analyse Belarus's export growth using export data at the HS-6 digit level for the 2004-2014 period. Our results show that Belarus's exports grew mainly due to growth in the price margin during the studied period 2004-2014. However, the extensive margin was important in export growth to some extent. Comparing the growth rate across final and intermediate goods reveals that although the share of final products in Belarus's exports is not very big (18.9\% in 2014), the average annual growth in exports of final products is higher than that of intermediate goods. Our investigation also shows that Belarus produces a wide range of commodities, but the share of the most of these commodities is not large; its exports depend on a restricted range of commodities. Moreover, most of the commodities are exported to Russia and Ukraine. Our results give us reason to assume that finding new markets for their new products is one of the main challenges for developing countries wishing to increase their exports by an extensive margin. This has important implications for how policy makers promote the trade and diversification of exports.
\end{abstract}

Key words: Export growth, Extensive margin, Intensive margin, Belarus.

JEL Classification: F14, F15, F63, O52.

Received: 29 November 2016 / Accepted: 9 February 2017 / Sent for Publication: 21 March 2017

\section{Introduction}

Since the early 1990s, Belarus has undertaken important reforms to transform its economic system from a planned economy to an open market economy. However, its econ-

\footnotetext{
${ }^{1}$ College of Economics and Trade, Hunan University, Yuelushan, Changsha, Hunan, 410079, People's Republic of China. E-mail: shavkat175@gmail.com, shujin zhu@126.com, ihtishamamin_99@yahoo.com, tenglong_zhong@126.com.
}

C 2017 by the authors; licensee Review of Economic Perspectives / Národohospodářský obzor, Masaryk University, Faculty of Economics and Administration, Brno, Czech Republic. This article is an open access article distributed under the terms and conditions of the Creative Commons Attribution 3.0 license, Attribution - Non Commercial - No Derivatives. 
omy underwent a substantial set-back during initial years of that transformation, with a decline in GDP 1.27 times between 1991 and 1995. Momentum picked up after 1995, with annual GDP growth between $0.2 \%$ and $11.45 \%$ in the period 1995-2014; the highest growth rate $(11.45 \%)$ was recorded in 2004 and the lowest growth $(0.2 \%)$ in 2009 (World Bank, 2015). The process of privatization in Belarus was slow compared to the majority of Eastern European countries and accompanied by long pauses. Although the role of the private sector has increased since 2011, most of the Belarusian economy remains state-controlled even today: in 2014 the share of state-controlled companies in gross value added was $49.9 \%$ (including $22.7 \%$ private companies with state ownership; Belarus Statistical Committee, 2015). The lack of any clear strategy and plan for the phased implementation of privatization resulted in Belarus losing its opportunity to use the privatization of enterprises as an engine for market reforms. To some extent this also negatively affected the country's development of international trade. Like its economic growth, Belarus's exports also declined between 1991 and 1995. From 1996 until 2014 the value of annual exports increased 6.6 times, but this growth was erratic and negative growth in exports was witnessed in several years during this period. This erratic export growth was not only caused by external factors (such as integration to the world market, crises, and economic sanctions), but also by internal factors; as Tochitskaya (2011) pointed out, Belarus's exports negatively impacted its efficiency as the share of low productivity goods in the exports structure increased. The above mentioned facts show that Belarus has not yet fully used its export potential.

This study aims to determine whether Belarus's export growth is explained by the extensive margin or intensive margin. Furthermore, export growth is also decomposed into price and quantity margins. To achieve our objectives we adopt two distinct methodologies, the count method and the shares method. These two methods of decomposition are complementary: the count method gives us information about the quantity of new goods, new relations, price growth and the quantity of products exported. The shares method, in turn, makes it possible to study the export growth margins (extensive, intensive, quantity and price) relative to other countries' exports. Both these methodologies have their own strengths and weaknesses.

\section{An overview of Belarus's exports}

Belarus's economy progressed well during our study period: GDP in constant prices increased from 27.6 billion US dollars in 2004 to 47.3 billion dollars in 2014 (171.4\%) with average annual growth of $5.53 \%$ (Real GDP during this period increased by $268.4 \%$ ) but this growth was not steady. The highest growth rate was recorded in 2004 $(11.45 \%)$, and the lowest was in $2009(0.2 \%)$. Belarus's exports trend was in a similar vein: nominal exports increased by $277.28 \%$, but this varied across the years. The highest export growth rate was recorded in 2011 (30.4\%) and the lowest in 2009 (7.83\%), moreover, export growth was negative in 2005, 2009, 2013 and 2014.

Table 1 demonstrates the industries' shares in exports and their growth during 20042014. These calculations are based on the UN COMTRADE dataset (SITC Rev. 3). It is clearly seen that export growth varies widely across industries. Export growth in the four industries "Crude materials, inedible, except fuels", "Manufactured goods", "Machinery and transport equipment" and "Miscellaneous manufactured articles" was lower 
than Belarus's average export growth, while for some other industries exports grew at a rate much higher than the country's average. Table 1 also highlights that the individual industries' shares in Belarus's total exports have changed over the years. Industries such as "Food and live animals" and "Mineral fuels, lubricants and related materials" increased their share of exports, while industries such as "Manufactured goods" and "Machinery and transport equipment" decreased their share. These facts reveal that higher value-added products lost their importance in Belarus's export market. This trend can be explained on the grounds that these industries lost their competitiveness in the world market and that world demand for these products grew only mildly during the period studied.

The structure of exports, according to goods production stage (intermediate and final goods), did not undergo any substantial changes between 2004 and 2014. The share of intermediate goods in Belarus' total exports was 67.6\% in 2004 and $70.3 \%$ in 2014 while the share of final goods was $17.5 \%$ in 2004 and $18.9 \%$ in 2014 . We may therefore conclude that Belarus did not significantly increase the share of final goods in its exports.

Table 1. Industries' shares in Belarus's exports and their growth (2004 - 2014)

\begin{tabular}{clccc}
$\begin{array}{c}\text { Ind.code } \\
\text { (SITC 1- } \\
\text { digits } \\
\text { level) }\end{array}$ & Industry & \multicolumn{2}{c}{$\begin{array}{c}\text { Share in exports } \\
(\%)\end{array}$} & $\begin{array}{c}\text { Export } \\
\text { growth(\%) }\end{array}$ \\
\cline { 3 - 5 } & & 2004 & 2014 & $2004 /$ \\
\hline 0 & Food and live animals & 7.56 & 13.68 & 473.97 \\
1 & Beverages and tobacco & 0.64 & 0.66 & 273.04 \\
2 & Crude materials, inedible, except fuels & 3.61 & 2.14 & 155.44 \\
3 & Mineral fuels, lubricants and related materials & 26.91 & 33.52 & 326.79 \\
4 & Animal and vegetable oils, fats and waxes & 0.11 & 0.41 & 931.57 \\
5 & Chemicals and related products, n.e.s & 10.91 & 13.74 & 330.52 \\
6 & Manufactured goods & 18.11 & 13.10 & 189.48 \\
7 & Machinery and transport equipment & 20.95 & 13.71 & 171.94 \\
8 & Miscellaneous manufactured articles & 8.15 & 6.07 & 196.07 \\
9 & Commodities and transactions, n.e.s & 3.05 & 2.96 & 254.77 \\
& Total & 100.0 & 100.0 & 262.55 \\
\hline $\begin{array}{l}\text { Source: } \\
\text { SITC Rev }\end{array}$ 3. & & &
\end{tabular}

Like most post-soviet countries, Belarus's main export companies are situated in the capital, Minsk. For example, in $201358.3 \%$ of total exports were from enterprises based in Minsk and its region and businesses in Minsk city itself accounted for $39.4 \%$ (Belarus Statistical Committee, 2015).

During this period Belarus's exports became more specialized. We used the Gini coefficient to measure this specialization. Our results showed that the Gini coefficient increased from 0.901 in 2004 to 0.923 in 2014 (a coefficient of zero indicates that export shares are equally distributed across all commodities; an increase in the Gini coefficient 
implies an increase in specialization). This result shows that Belarus's exports increased in specialization, but also that Belarus's exports are highly concentrated on certain groups of commodities.

Similarly, Belarus's exports dramatically depend on only a few export markets. The top five export destinations accounted for $72 \%$ of Belarus' exports in 2004 . These countries are Russia (46\%), the UK (9\%), Netherland (7\%), Poland (6\%), and Ukraine (4\%). The country's dependence on its five most important export destinations did not change during the period we studied. However, Poland dropped out of the list and Germany joined in 5th place. Furthermore, Ukraine's share significantly increased from $4 \%$ in 2004 to $12 \%$ in 2014, while the shares of exports to the UK and the Netherlands decreased. For a variety of geographical, historical and cultural reasons, Belarus has strong trade ties with Russia; although its share of Belarus's total exports decreased over the study period, Russia is still the destination for $42 \%$ of Belarusian exports (2014). The recent crises in Russia and Ukraine have had a negative influence on Belarus's export growth. For example, Ukraine imported USD 5055.5 million of Belarusian products in 2012 but this fell to USD 3586.6 million in 2013 and increased only slightly to USD 3970.8 million in 2014 (State Statistics Service of Ukraine, 2016).

This situation was exacerbated by the fact that production of some of Belarus's main export products strongly depends on raw resources imported from Russia. For example, the Belarusian refineries processing 24 million tons (in 2016) of oil annually, but just 1.6 million tons of that oil is extracted in Belarus, and more than 22 million tons of oil are imported from Russia.

The top ten most exported products in 2004 were as follows: petrol oil (share in exports $18.59 \%)$; non-crude oil $(6.36 \%)$; potassium chloride $(5.62 \%)$; tractors $(2.49 \%)$; combined refrigerator-freezers $(2.05 \%)$; dumpers designed for off-highway use $(2.03 \%)$; bars \& rods of iron/non-alloy steel (1.84\%); petroleum oils and oils obtained from bituminous minerals (1.84\%); vehicles other than railway or tramway $(1.47 \%)$; cane/beet sugar \& chemically pure sucrose $(1.43 \%)$. These ten commodities accounted for $43.73 \%$ of Belarus' total exports in 2004. The structure of the top 10 most exported products changed over the period studied and in 2014 were as follows: petrol oil (21.76\%), potassium chloride $(7.67 \%)$, non-crude oil $(6.11 \%)$, petroleum oils and oils obtained from bituminous minerals $(3.23 \%)$, motor vehicles $(2.41 \%)$, tractors $(2.02 \%)$, cheese $(1.89 \%)$, bituminous $(1.31 \%)$, bars \& rods of iron/non-alloy steel $(1.22 \%)$, high tenacity yarn $(1.10 \%)$. These products accounted for $48.72 \%$ of Belarus's total exports in 2014. Motor vehicles, cheese, bituminous mixes, and high tenacity yarn replaced combined refrigerator-freezers, dumpers, vehicles other than railway or tramway and cane/beet sugar \& chemically pure sucrose in the top ten exported commodities list.

\section{Literature review}

Much of the current literature on countries' export performance and potential pays particular attention to the decomposition of export growth into extensive and intensive margins, and to the price and quantity components of exports. These studies are mainly based on the model put forward by Melitz (2003), which is based on two key elements: the heterogeneous productivity of firms and the sunk cost. These two points lead to the 
conclusion that less productive firms are unable to bear the additional (compared to domestic sales) costs and are therefore forced to leave the world export market.

Some studies have concluded that extensive margin plays an important in export growth, while others have pointed out that the intensive margin contribution prevailed in export growth. One reason for these different conclusions might be that the researchers applied different approaches to decompose export growth into extensive and intensive margins; or used different definitions of the extensive and intensive margins and/or different data sets. For example, Bernard at al. (2009), Eaton at al. (2004), and Coughlin (2012) define the extensive margin as change in the quantity of exporting firms, and the intensive margin as change in the export volume among incumbent exporters (or average exports per firm), as these studies used firm-level data. Some authors, such as Amurgo-Pacheco and Pierola (2008), and Amiti and Freund (2008) used product level data and defined the extensive margin as the number of new export varieties and export destinations, while the intensive margin is the growth in the export of existing varieties. Other authors as Felbermayr and Kohler (2006) and Helpman et al. (2008) used country-level data for the decomposition of export growth. They define the extensive margin as the variety of new trade relationships (or closed existing relationships) while the intensive margin is the level of trade based on existing relationships (increased or reduced). However, in recent studies, researchers such as Dutt et al. (2011), Bingzhan (2011), and Turckan (2014) have decomposed export growth into extensive and intensive margins based on country-product level data.

Despite the different approaches applied by these researchers, all of them have made a significant and tangible contribution to the development of the theoretical framework and decomposition methodologies in the study of the contribution of extensive and intensive margins in the export growth. We discuss below some studies that provide the logic, theoretical background and methods adopted in this study.

Besedes and Prusa (2011) explained that one of the reasons why developing countries have difficulties in increasing their exports is that export growth is mainly due to the intensive margin, as many new relationships fail to deepen in the long run. Similarly, Amurgo-Pacheco and Pierola (2008) studied 24 developed and developing countries' exports for the period 1990-2005 and concluded that export growth was mainly a result of intensive margin growth.

Some research studies have paid heed to the effect of an economy's integration with the rest of world on its exports margin. For example, Dutt et al. (2011) found that WTO membership significantly increased the extensive export margin but negatively affected the intensive margin. The importance of trade liberalization in the extensive margin within NAFTA countries was emphasized by Kehoe and Ruhl (2003) and Romalis (2007). By contrast, Rishav (2015) did not find any positive impact on the extensive or intensive margins between WTO member country pairs, but found that WTO membership increased developing countries' exports in the extensive margin. Negligible differences in growth in the extensive and intensive margins were captured between EU and non-EU countries by Turckan (2014) for Austria's exports. To sum up, these studies showed that membership in a trade union significantly increases a country's extensive export margin. 
Hummels and Klenow (2005) examined why big economies (countries) export a larger quantity and wider range of products in comparison to small economies. They developed the cross-exporter analogue of Feenstra's new varieties adjustment and decomposed export into three margins: extensive margin, price and quantity margins. In contrast to the previously mentioned studies, which merely define and calculate the extensive margin as the number of new products, firms or partners in country's export, they define the extensive margin as a weighted count of exporter categories (number of products) relative to the world's categories. This methodology has been widely used in other research studies for the decomposition of export growth. Bingzhan (2011) enhanced the Hummels and Klenow method of decomposition of export growth and decomposed trade growth rates rather than export shares.

From the above literature it is clear that we can decompose Belarus's exports into extensive and intensive margins and also into price and quantity margins following Hummels and Klenow (2005), Bingzhan (2011) and Turckan (2014) among others.

\section{Data}

The data on Belarus's exports at HS 6-digit level in U.S. dollars was gathered from the UN-COMTRADE online database. This study covers the period from 2004 to 2014, although there were some changes in HS classifications in 2007 and 2012. However, we collected data on Belarus's exports at HS-2002 classification. We did not convert the data to HS-1992 or HS-1996 as some researchers did, firstly because the HS-2002 classification includes 5225 categories of product, whereas HS-1992 and HS-1996 contain only 4875 and 5035 types of products respectively, thus by using (or by converting to) a previous version of HS classification we would lose some new product types. Second, export data was available to download for most countries in HS-2002 classification, so instead of downloading in HS-1992 (or HS-1996), we downloaded in HS-2002 for the available countries and used HS-1996 only for countries for which data was not available in HS-2002. Further, we converted that HS-1996 data to HS-2002. Additionally, we converted the HS codes at six digit level to the United Nations Broad Economic Categories (BEC) classification system for the purpose of distinguishing between exports of intermediate goods and final goods, and to the SITC Rev.3 classification system in order to analyze Belarus's exports at the industry level. Macroeconomic data such as GDP and the export growth rate were downloaded from the World Bank online database.

\section{Methodology}

We applied two distinct methods, the count method and the shares method, to decompose exports into extensive and intensive margins. Furthermore, we decomposed the intensive margin into price and quantity margins. In the count method, the extensive margin is calculated by counting the number of exported products and destinations, while the intensive margin is calculated as the volume of trade per product. One of the main disadvantages of this methodology is that we cannot assess the contribution of new products or countries to the export growth. However, the results using this method demonstrate the increment of new products and destinations in the exports of a country more clearly than other methods. Turckan (2014) found that the count method gives similar results to any other method and that it is also easy to understand and estimate. 
This is why we adopted the count method to find the importance of the extensive margin in export growth and also to discover which new products and destinations appeared on Belarus's export market during the study period. According to the count method, the extensive margin $\left(E M_{j t}^{I}\right)$ is defined as the number of products $i$ that Belarus exported to trading partner country $j$ :

$$
E M_{j t}^{I}=\sum_{i \in I j t} n_{j t}= \begin{cases}1 & \text { if } p_{j i t} q \\ 0 & \text { overvise }\end{cases}
$$

where $I_{j t}$ is the set of products exported from Belarus to destination country $j$, in year $t$. On the other hand, the intensive margin $I M_{j t}^{I}$ is defined as value of 'common' products that Belarus exported to country $j$ in periods $t$ and $t+1$

$$
I M_{j t}^{I}=\sum_{i \in I} p_{j i t} q_{j i t}
$$

where $I_{j c}$ represents the set of products that were exported to country $j$ in both $(t$ and $t+1$ ) periods.

Now we move on to explain decomposition by the shares method, which was developed by Hummels and Klenow (2005), and is based on calculation of the share of a country's exports relative to world exports. Let us denote Belarus' exports by $m$ and use the rest of the world (ROW) as a reference country, denoted by $k$. This approach defines the extensive margin as the weighted count of categories (products) that a given country exports relative to the categories exported by the rest of world. The extensive margin calculated using the shares method is thus expressed as:

$$
E M_{m j}=\frac{\sum_{i \in I_{m j}} p_{k j i} q_{k j i}}{\sum_{i \in I} p_{k j i} q_{k j i}}
$$

where, $I_{m j}$ is the set of observable categories in which country $m$ has positive exports to country $j$ and $I$ is the set of products exported by the world to country $j$.

The intensive margin for Belarus's exports to country $j$ for year $t$ is defined as Belarus's nominal exports relative to $k$ 's nominal exports in those categories in which Belarus exports to $j$ and can be expressed as:

$$
I M_{m j}^{I}=\frac{\sum_{i \in I_{m j}} p_{m j i} q_{m j i}}{\sum_{i \in I_{m j}} p_{k j i} q_{k j i}}
$$

where $m_{m j i} q_{m j i}$ is the value of total exports from Belarus to destination country (or region) $j$ and $m_{k j i} q_{k j i}$ are the total world exports of the set of goods which Belarus exports to destination country $j$.

The intensive margin, following Hummels and Klenow (2005), can also be decomposed into price $\left(P_{m j}\right)$ and quantity $\left(X_{m j}\right)$ components: 


$$
I M_{m j}^{I}=P_{m j} \times X_{m j}
$$

The price index measures the weighted average ratio of Belarus' prices to ROW's prices for each product at six digit level, where the weights are the shares of each product category in the total exports of the common set:

$$
P_{m j}=\prod_{i=I m j}\left(\frac{P_{m j i}}{P_{k j i}}\right)^{w_{m j i}}
$$

where, $P_{m j i}$ and $P_{k j i}$ are the prices of product $i$ exported by Belarus $(m)$ and the ROW $(k)$ respectively to country $j, w_{m j i}$ is the logarithmic mean of $S_{m j i}$ (the share of category $i$ in Belarus's exports to $j$ ) and $S_{k j i}$ the share of category $I$ in the world's exports to $j$ )

$$
S_{m j i}=\frac{p_{m j i} q_{m j i}}{\sum_{i \in I_{m j}} p_{m j i} q_{m j i}}, \quad S_{k j i}=\frac{p_{k j i} q_{k j i}}{\sum_{i \in I_{m j}} p_{k j i} q_{k j i}}, \quad w_{m j i}=\frac{\frac{s_{m j i}-s_{k j i}}{\ln s_{m j i}-\ln s_{m j i}}}{\sum_{i \in I_{m j}} \ln s_{m j i}-\ln s_{k j i}}
$$

The extensive and intensive margins in both methods have static concept, thus to estimate growth in the extensive margins $\left(G_{E M}\right)$, intensive margins $\left(G_{I M}\right)$, price $\left(G_{p}\right)$ and quantity $\left(G_{q}\right)$ we applied the compound annual growth rate (CAGR) which is given as

$$
G_{E M}=\left(\frac{E M_{j t+1}^{I}}{E M_{j t}^{I}}\right)^{\frac{1}{t}}-1
$$

Using these methods (the count and share methods) we calculated the extensive and intensive margins of Belarus' exports at world level, for the largest fifteen export destination countries and also for five regions. We chose the 15 countries that had the biggest share in Belarus' exports in 2014. We used UN classification for the composition of countries into regions, and we included Commonwealth Independent States (CIS) countries. In addition, we estimated the extensive and intensive margins of exports for different types of goods according to their production stage (intermediate goods, final goods, and all goods).

\section{Results and discussion}

Table 2 presents the extensive margin of Belarusian exports obtained through the count method of decomposition. The first and second columns of Table 2 present the share of each partner country (region) in Belarus's exports in 2004 and 2014 respectively. The third column shows the growth rate of exports to each country (region) during 20042014. The next columns (fourth through to twelfth) show the extensive margins (the number of exported products to the destination country or the number of productdestination pairs exported to the region), and their annual growth rate for total, intermediate and final goods in 2004 and 2014. From this data, we can see that Belarus's average export growth rate was $10.13 \%$ during this time. The growth rates of exports to 
some countries (namely Ukraine, Italy, Kazakhstan, Brazil, Turkmenistan, and Germany) were higher than the average growth rate of Belarus's exports, and as a result the share of these countries in Belarus's exports increased significantly. The types of exported products also increased during this period: the number of country-product relationships in 2014 was 22666, compared to 17570 in 2004 with an annual growth rate of $2.58 \%$. Although the number of country-product relationships for final goods is less than for intermediate goods, their annual growth rate is higher than for intermediate goods. The extensive margin growth rates are higher for countries such as Brazil, Turkmenistan, India, and Kazakhstan than rest of countries in our sample. We also found significant differences in the growth of the extensive margin across regions: it is higher for regions such as Oceania, Asia, America, and CIS than Africa and Europe. However, the value of these commodities in exports was not big. The number of country product relationships to Europe and Africa did not increase significantly, indeed the number of exported products decreased to some of the European countries like the Netherlands, Italy, the UK, and Latvia. These results suggest that Belarusian exporters found new destinations for their products, which are mainly developing countries.

Table 3 shows the growth of the intensive margin and its price and quantity components across countries and regions obtained through the count method. We can observe that the annual growth in the intensive margin of Belarusian exports to the world is $18.13 \%$. As we expected, growth in the intensive margin was higher than in the extensive margin of Belarus's exports during the period studied. However, the extensive margin growth rate is higher than intensive margin growth rate to some countries (for example, Germany, Lithuania, Kazakhstan, Poland, Brazil, Turkmenistan, and India). The intensive margin growth rate is also higher for final goods $(24.61 \%)$ compared to intermediate goods $(16.51 \%)$, as seen for the extensive margin growth. Apparently, Belarus tended towards greater specialization in exports of final goods during the studied period, mainly as a result of exports of final goods to CIS countries increasing, and particularly to the Russian market. The most interesting fact is that for most countries the annual growth of the intensive margin is negligible, which enables us to suggest that Belarusian exporters had difficulties in making long-term relationships during this period.

Further decomposition of the intensive margin into quantity and price components reveals the importance of quantity margins in export growth. The growth rate of the quantity component for total goods is $10.63 \%$ while the growth rate of the price component stands at $7.51 \%$. The growth rates of the quantity and price components for intermediate goods are $8.23 \%$ and $8.28 \%$, and for final goods $6.14 \%$ and $18.48 \%$ respectively. It is clear from the results reported in Table 3 that the contributions of the price and quantity components for intermediate goods are similar, while the quantity component is more important for final goods. 


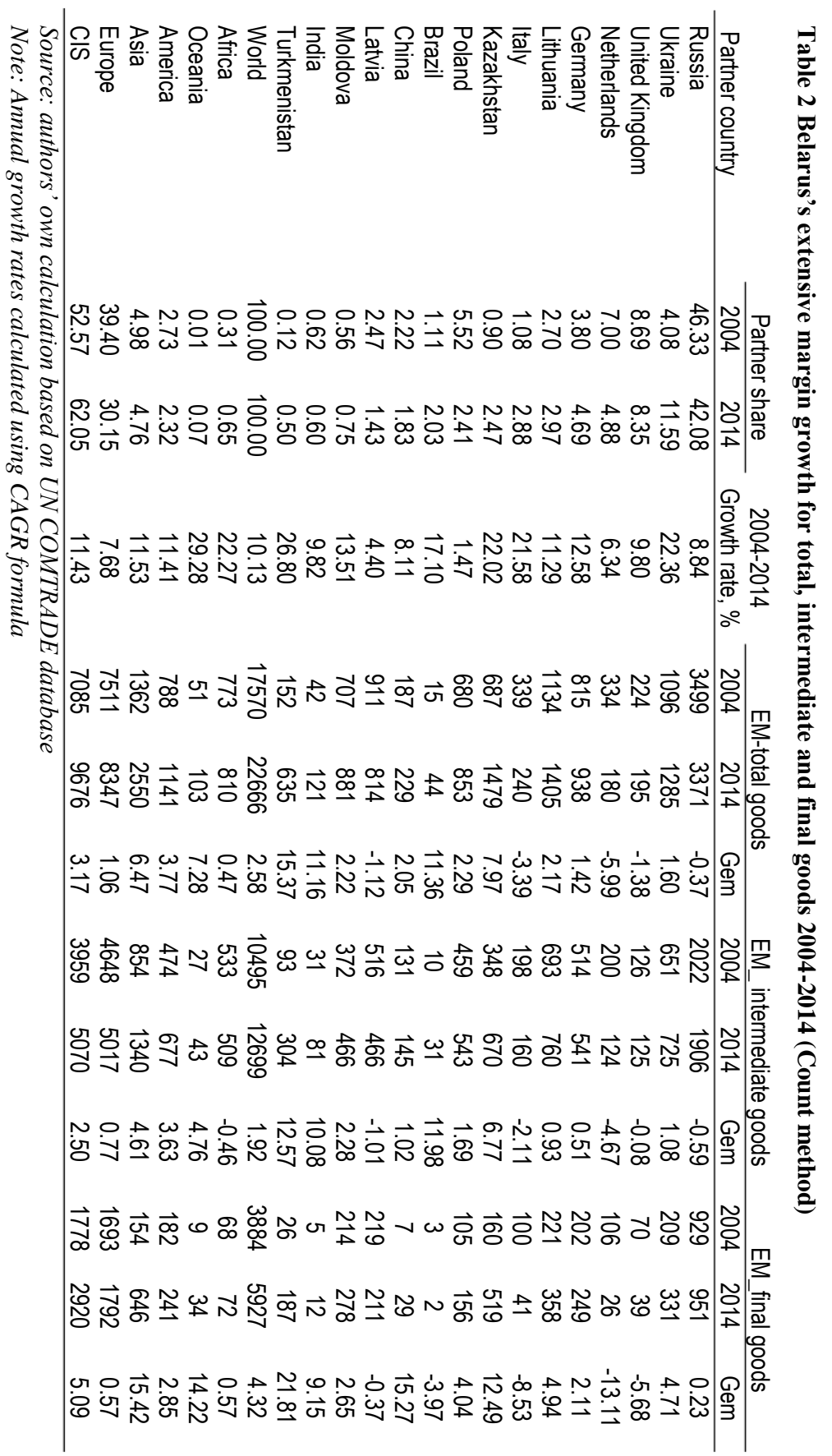


Table 3. Belarus's intensive margin growth and its price and quantity components for total, intermediate and final goods, 2004-2014 (Count method)

\begin{tabular}{|c|c|c|c|c|c|c|c|c|c|}
\hline \multirow{2}{*}{ Partner } & \multicolumn{3}{|c|}{ Total goods } & \multicolumn{3}{|c|}{ Intermediate goods } & \multicolumn{3}{|c|}{ Final goods } \\
\hline & g_IM & G_pr & G_q & g_IM & G_pr & G_q & g_IM & G_pr & G_q \\
\hline Russia & 8.861 & 2.241 & 6.621 & 4.565 & 1.203 & 3.362 & 22.751 & 5.565 & 17.187 \\
\hline Ukraine & 6.087 & 1.110 & 4.977 & 8.526 & 1.533 & 6.994 & 0.297 & 0.053 & 0.243 \\
\hline United Kingdom & 0.599 & 0.743 & -0.145 & 0.848 & 1.054 & -0.206 & -0.002 & 0.003 & -0.005 \\
\hline Netherlands & 0.294 & 0.438 & -0.144 & 0.406 & 0.619 & -0.213 & 0.009 & 0.000 & 0.009 \\
\hline Germany & 0.874 & 0.426 & 0.448 & 1.166 & 0.577 & 0.589 & 0.206 & 0.078 & 0.128 \\
\hline Lithuania & 0.797 & 0.193 & 0.604 & 1.046 & 0.252 & 0.795 & 0.155 & 0.038 & 0.117 \\
\hline Italy & 1.906 & 0.504 & 1.402 & 2.705 & 0.715 & 1.990 & 0.010 & 0.003 & 0.007 \\
\hline Kazakhstan & 0.449 & 0.074 & 0.375 & 0.190 & 0.029 & 0.161 & 0.509 & 0.102 & 0.408 \\
\hline Poland & 0.528 & 0.143 & 0.385 & 0.722 & 0.196 & 0.526 & 0.042 & 0.017 & 0.025 \\
\hline Brazil & 0.325 & 0.178 & 0.147 & 0.462 & 0.253 & 0.210 & 0.000 & 0.000 & 0.000 \\
\hline China & 0.302 & 0.196 & 0.106 & 0.381 & 0.246 & 0.135 & 0.109 & 0.121 & -0.012 \\
\hline Latvia & 0.129 & 0.124 & 0.005 & 0.169 & 0.170 & -0.001 & 0.042 & 0.011 & 0.031 \\
\hline Moldova & 0.128 & 0.054 & 0.074 & 0.145 & 0.066 & 0.079 & 0.057 & 0.014 & 0.043 \\
\hline India & 0.058 & 0.050 & 0.008 & 0.082 & 0.072 & 0.011 & 0.000 & 0.000 & 0.000 \\
\hline Turkmenistan & 0.072 & 0.013 & 0.060 & 0.025 & 0.002 & 0.023 & 0.016 & 0.002 & 0.014 \\
\hline World & 18.131 & 7.505 & 10.626 & 16.511 & 8.229 & 8.282 & 24.611 & 6.144 & 18.467 \\
\hline Africa & 0.198 & 0.038 & 0.161 & 0.243 & 0.044 & 0.199 & 0.003 & 0.002 & 0.001 \\
\hline Oceania & 0.001 & 0.000 & 0.000 & 0.000 & 0.000 & 0.000 & 0.002 & 0.001 & 0.001 \\
\hline America & 0.407 & 0.227 & 0.179 & 0.474 & 0.307 & 0.168 & 0.109 & 0.004 & 0.106 \\
\hline Asia & 1.079 & 0.504 & 0.576 & 1.335 & 0.633 & 0.702 & 0.418 & 0.171 & 0.247 \\
\hline Europe & 5.325 & 2.500 & 2.824 & 7.162 & 3.452 & 3.709 & 1.031 & 0.183 & 0.848 \\
\hline CIS & 14.938 & 3.623 & 11.315 & 12.182 & 2.839 & 9.343 & 24.526 & 5.983 & 18.544 \\
\hline
\end{tabular}

Source: authors' own calculation based on UN COMTRADE database

The results of the shares method of decomposition (Klenow's method) for total, intermediate and final goods are presented in Appendix in Tables 4, 5 and 6 respectively. The estimated values of the extensive margin in 2004 and 2014 are given in the second and third columns respectively, while its growth is presented in the fourth column. The intensive margins for 2004 and 2014 are given in the fifth and sixth columns, and intensive margin growth is shown in the seventh column. The eighth and ninth columns present the price margins for 2004 and 2014 respectively. Growth in the price margin is shown in the tenth column. Similarly, the quantity margins for 2004 and 2014 are given in the eleventh and twelfth columns respectively, while growth in the quantity margin is presented in the last column. As can be seen from Table 4, Belarus's export growth is mainly driven by intensive margin growth. The contribution of the intensive margin to export growth is higher than that of the extensive margin, which is negative during this period. Considering the growth rates of the extensive and intensive margins at the country level reveals that the contribution of the extensive margin to export growth is only higher than that of the intensive margin for six of the 15 selected countries. These countries are the Netherlands, Poland, China, Latvia, Moldova, and India. The same is true for Russia, where both extensive and intensive margins declined, but the extensive margin declined less than the intensive margin. Comparing the extensive and intensive 
margins across regions reveals that extensive margin growth is only higher than intensive margin growth for Asia. For other regions, Belarus's exports mainly grew as a result of intensive margin growth during our study period.

Furthermore, comparing the price and quantity margins of Belarus's exports to the entire world showed that quantity margin growth rate was $2.04 \%$, but the price margin declined (at a rate of $-0.01 \%$ ) during 2004-2014. Therefore, the growth of Belarus's exports to the entire world was mainly driven by the quantity margin. This finding is similar to those of Otamurodov et al. (2016), who found that Kazakhstan's export growth is largely driven by quantity. Comparing these margins across countries and regions gave similar results; for five of the chosen 15 countries and two regions (Asia and Europe) the price margin had negligible growth, whereas for other destinations the price margin had negative growth. Besides this, price margin of exports indicates that Belarusian products are generally cheaper than products from the rest of the world (the price margin value is 0.996 ), but more expensive than products from some leading developing countries like India and China. Veeramani and Gupta (2014) found price margin for India and China is 0.856 and 0.567 , respectively. The analysis of the quantity component (margin) of export growth gives us information about the contribution of quantity growth to overall export growth and about the share of Belarus's exported products in the destination countries' imports. From these results, we can see that Belarus's quantity component growth of exports to the world was $2.04 \%$, but that there are considerable differences across countries and regions, ranging from $0.67 \%$ to $17.42 \%$. The growth rates of the quantity margin were higher for countries, such as Ukraine (17.425), Italy (16.50\%), Turkmenistan (10.38\%), Kazakhstan (8.08\%) and Germany (7.14\%) than rest of countries in our sample. Further examining the quantity margin of Belarus's exports revealed that Belarus significantly increased its share in the imports market of Ukraine, Moldova, and Kazakhstan by 20 percent, 12 percent, and four percent respectively during the study period. Looking across regions, the quantity margin shows that Belarus's products have a small share in CIS countries and the European region, while their share in other regions is negligible.

We now turn to compare the results of the decomposition of export growth for intermediate and final goods presented in Tables 5 and 6 . Comparing the results for intermediate and final goods, we can see that for both groups of goods the export growth to the world is driven by intensive margin growth. The extensive margin for both groups of goods declined during 2004-2014. However, the rate of decline in the extensive margin for intermediate goods $(-0.42)$ is a little greater than for final goods $(-0.08)$. The growth rate in the intensive margin for final goods is a little higher $(2.76 \%)$ than for intermediate goods $(2.34 \%)$. Moreover, these results highlight that the extensive margin's contribution to export growth was higher than the intensive margin's contribution for final goods for eight countries, while this was only true for intermediate goods for four countries. Another finding is that intensive margin growth for most of the countries is negative for final goods, but not for intermediate goods. We can conclude that final goods are an important source of extensive margin growth, while intermediate goods extend the intensive margin.

Further decomposition of export growth into price and quantity components revealed that the growth rate of the price component of final goods to many destinations showed relatively good results, whereas for intermediate goods the price components showed 
negative growth for eight countries and all regions. The highest growth rates for the price margins for intermediate goods were to Latvia (1.16\%) and India (1.12\%), and for final goods to Brazil $(0.86 \%)$. A price margin comparison of intermediate and final goods shows that final goods exported for higher prices than intermediate goods. The value of Belarus's price margin for final goods exported to China was above one (1.010 in 2004 and 1.015 in 2014) which means that Belarus's final goods are more expensive compared to final goods exported to China from the rest of the world. The same results can be seen for final goods exported to Asia in 2014. Thus, we conclude that Belarus's final goods exported to the Asian region are generally of high quality.

As can be seen from the results presented in these tables, the growth rate in the quantity component for intermediate goods was $2.34 \%$, and for final goods $2.76 \%$ during this period. In other words, the annual growth rate of the quantity component was a little higher for final goods. For regions, these results show that intermediate goods have a significant growth rate in the quantity margin to regions such as Oceania $(47.81 \%)$, Africa (10.17\%) and America (6.20\%). There was significant growth in final goods exports to Oceania and Asia at a rate of $18.33 \%$ and $6.75 \%$, respectively. Turning to country level results, the highest growth rates in the quantity margin for intermediate goods were to countries such as Ukraine (23.88\%), Italy (18.09\%), Kazakhstan (11.44\%), Turkmenistan (10.54\%), and Germany (8.7\%), and for final goods to countries such as Turkmenistan (19.85\%), China (18.41\%) and Moldova (8.88\%).

Belarus's exports have tended to decline during recent years. For instance, only in 2013 Belarus's exports declined more than $19 \%$. However, our results show that this downward trend in exports is not observed for all exported commodities. The declining trend occurred in some key export commodities such as petrol oil (29.84\%), non-crude oil (29.5\%), motor vehicles $(41.3 \%)$, and potassium chloride $(23.21 \%)$, while other commodities such as bituminous mixes (768\%), meat of bovine animals (296\%), high tenacity yarn (70.24\%) and cheese (12.34\%) exports showed higher growth rates compared to average export growth.

\section{Conclusion}

This paper has studied Belarus's export growth by decomposing it into the extensive and intensive margin. We used two methodologies to decompose the export growth, the count method, and the export shares method. Belarus's exports increased 2.63 times over the period 2004-2014, but this growth was not sustained, and in recent years its exports have declined by $19.2 \%$ in 2013 and $1.8 \%$ in 2014 . The main problem affecting Belarus's exports is the country's dependence on too few export markets: in 2014 Belarus's five biggest partner countries took a $71.59 \%$ share of all its exports, In addition to this, the crisis that began in Russia and Ukraine at the end of 2013 negatively affected Belarus's exports (these two countries were the destination for $53.67 \%$ of Belarus's exports in 2014). The results of both decomposition methods showed that Belarus's exports had grown primarily due to intensive margin growth during 2004-2014. Nevertheless, the extensive margin was important in the growth of exports to certain destinations (the Netherlands, Poland, China, Latvia, Moldova, and India).

The count method decomposition results showed that the number of country-product relationships increased from 17570 in 2004 to 22666 in 2014. The number of products 
exported to countries such as Brazil, Turkmenistan, India, and Kazakhstan significantly increased. Belarus's exporters tend to find new markets for their products; exports of final goods significantly increased (with an annual growth rate of $4.2 \%$ ), but these products did not make up a large share of the total exports. Furthermore, the results of the decomposition into price and quantity margins obtained through the count method showed that the growth rate of the price component was higher for intermediate goods, while the growth rate of the quantity component was higher for final goods.

The results of the decomposition of export growth obtained through the export shares method also confirmed the importance of the quantity margin in Belarus's export growth. The contribution of the extensive margin was higher than that of the intensive margin for countries such as the Netherlands, Poland, China, Latvia, Moldova, India, and Russia, but these growth rates were marginal. Comparing the extensive and intensive margin growth rates of Belarus's export growth at the regional level indicated that extensive margin growth was more important in the growth of exports to Asia and particularly to CIS countries. Most likely, an increase in commodities exported to Asian countries had ensured the diversification of export destinations. However, Belarus's export dependence on the Russian market did not significantly decrease during the period 2004-2014, thus any geographic diversification has not been sufficient for Belarus to decrease its dependence on Russian market.

The decomposition of the intensive margin of export growth into price and quantity margins by the shares method showed that Belarus's exported products are cheaper than exported products from other countries. Moreover, the growth rate of the price component was negative for the entire world and for most of our selected countries as well. Compare to the most developed countries, Belarus's export products have a lower quality level. Nevertheless, these products' quality (price) level is higher compared to most developing countries. An examination of the quantity margin at country level showed that the quantity margin growth rate was significant for countries such as Ukraine, Italy, Turkmenistan, Germany, Kazakhstan and the United Kingdom.

The results of the shares method for intermediate and final goods further pointed out that an increase in final products in a country's exports creates more conducive conditions for stable export growth. We find that Belarus's final product export growth has grown for many countries due to the extensive margin. We can thus conclude that increasing exports of final products gives the exporters greater chances of finding new markets.

Belarus exports a wide range of products, but the value of the majority of its exported products is not substantial in relation to its total exports. In other words, Belarus's export dependence on a few markets and a few products makes its exports very sensitive to the situations of its major trade partners and to price fluctuations of its main products.

Our findings have a number of important implications for the promotion of trade and diversification. Previous research emphasized that the main source of extensive margin growth for developing countries is the diversification of exports. Our findings support the fact that diversification of exports is important for extensive margin growth. However, our results also give us reason to believe that the problem for developing countries is not the production of new products, but rather finding their way into new markets with their new products. For example, Belarus produces a wide range of products, in- 
cluding many products with high added value, but exports these products only to a few countries (Russia, Lithuania, Ukraine, Latvia, Kazakhstan and Poland).

On the basis of our findings we recommend that Belarus focus on geographical diversification of its exports to ensure its sustainable growth. Belarus has good opportunities to increase its exports to a wide variety of countries because it produces many kinds of products, but at present most of these are exported to Russia and other CIS countries. For example, in 2014 Belarus exported 3371 types of products to Russia, but only 229 types of products to China and 121 types of products to India. To achieve diversification it is important to reduce the trade price, mainly by facilitating exports to reduce transportation costs. Quantity-driven export growth requires large amounts of natural resources. Belarus is not as abundant in resources as other CIS countries, so to achieve sustainable export growth Belarus needs to foster favorable conditions for qualitydriven growth. This means it would be worthwhile for Belarus to modernize its production techniques, encourage innovation, and improve efficiency, all of which would enhance the competitiveness of Belarus's exports and might ease entry into and retention of new markets.

Acknowledgements: We are thankful to anonymous reviewers for their valuable comments and suggestions, and we highly appreciate the journals' editors for editing service.

Disclosure statement: No potential conflict of interest was reported by the authors.

\section{References}

AMITI, M. \& FREUND, C. (2008), An Anatomy of China's Trade Growth. World Bank Policy Research Working Paper, no.4628, 1-29.

AMURGO-PACHECO, A. \& PIEROLA, M. D. (2008), Patterns of Export Diversification in Developing Countries, World Bank Policy Research Working Paper no.4473, 134.

BESEDES T., \& PRUSA T.J. (2011). The Role of Extensive and Intensive Margins and Export Growth. Journal of Development Economics, 96(2), 371-379. DOI: 10.1016/j.jdeveco.2010.08.013

BERNARD, A.B., JENSEN, J.B., REDDING, S.J., \& SCHOTT, P.K. (2009). The margins of US trade. American Economic Review, 99(2), 487-493. DOI: $\underline{10.1257 / \text { aer.99.2.487 }}$

BINGZHAN, S. (2011). Extensive margin, quantity and price in China's export growth. China Economic Review, 22(2), 233-243. DOI: 10.1016/j.chieco.2011.01.007

COUGHLIN, C. C. (2012). Extensive and Intensive Trade Margins: A State-by-State View. [Online] Federal Reserve Bank Working Paper. Available from: http://research.stlouisfed.org [accessed 18/12/2015]

DUTT, P., MIHOV, I., \& Van ZANDT, T. (2011), Does WTO Matter for the Extensive and the Intensive Margins of Trade? CEPR Discussion Papers, no. 8293, (pp.1-34). 
EATON, J., ESLAVA, M., KUGLER, M., \& TYBOUT, J. (2008). Exports Dynamics in Colombia: Transactions Level Evidence. Borradores de Economia, no.522, 1-39.

FEENSTRA, R.C., (1994). New Product Varieties and the Measurement of International Prices. The American Economic Review, 84(1), 157-177.

FELBERMAYR, G. J., \& KOHLER W.K. (2004). Exploring the intensive and extensive margins of world trade. CESifo working papers, no.1276, (pp.1-46).

HELPMAN, E., MELITZ, M., \& RUBINSTEIN, Y. (2008). Estimating Trade Flows: Trading Partners and Trading Volumes. The Quarterly Journal of Economics, 123(2), 441-487. http://doi.org/10.1162/qjec.2008.123.2.441

HUMMELS, D., \& KLENOW, P. J. (2005). The Variety and Quality of a Nation's Exports. American Economic Review, 95(3), 704-723.

KEHOE, T. J., \& RUHL, K. J. (2003). How Important Is the New Goods Margin in International Trade? Federal Reserve Bank of Minneapolis Research Department Staff Report, (pp.1-41).

MELITZ, M. J., (2003), The Impact of Trade on Intra-Industry Reallocations and Aggregate Industry Productivity. Econometrica, 71(6), 1695-1725.

OTAMURODOV Sh, ZHU Sh., ZHONG T., \& HAQ I. (2016). The role of extensive margin and intensive margin in Kazakhstan's export growth. Ecoforum, Volume 5, 2(9), 9-16.

RISHAV B., (2015). Reconciling the WTO Effects on Trade at the Extensive and Intensive Margins. International Economic Journal, 29(2), 231-257. DOI: $\underline{10.1080 / 10168737.2015 .1020622}$

ROMALIS, J., (2007). NAFTA's and CUSFTA's Impact on International Trade. The Review of Economics and Statistics, MIT Press, vol. 89(3), 416-435.

TURKCAN, K., (2014). Investigating the Role of Extensive Margin, Intensive Margin, Price and Quantity Components on Turkey's Export Growth during 1998-2011. MPRA Paper, no.53292, (pp.1-72).

TOCHITSKAYA, I., (2011). How to Increase Sophistication of Belarus' Export Basket. IPM Research Center Policy Paper, PP/02/2011, (pp.1-11).

Foreign Trade of the Republic of Belarus. Statistical Book 2015. [Online] National Statistical Committee of the Republic of Belarus. Available from: http://www.belstat.gov.by/upload/. [Accessed 06/05/2016] (pp19-98)

Ukraine's Foreign Trade. Statistical Yearbook. [Online] State Statistics Service of Ukraine. Kyiv 2016 Available from: http://www.ukrstat.gov.ua/druk/publicat/kat_u/2016/zb/06/Zb_zt2016pdf.zip. [Accessed 13/02/2017] (p. 26)

VEERAMANI, C., \& GUPTA, P. (2014). Extensive and Intensive Margins of India's Exports : Comparison with China. (IGIDR working paper WP-2014-011). Indira Gandhi Institute of Development Research, 1-38. [Online] Available from: http://www.igidr.ac.in/pdf/publication. [Accessed 05/03/2016] 


\section{Appendix}

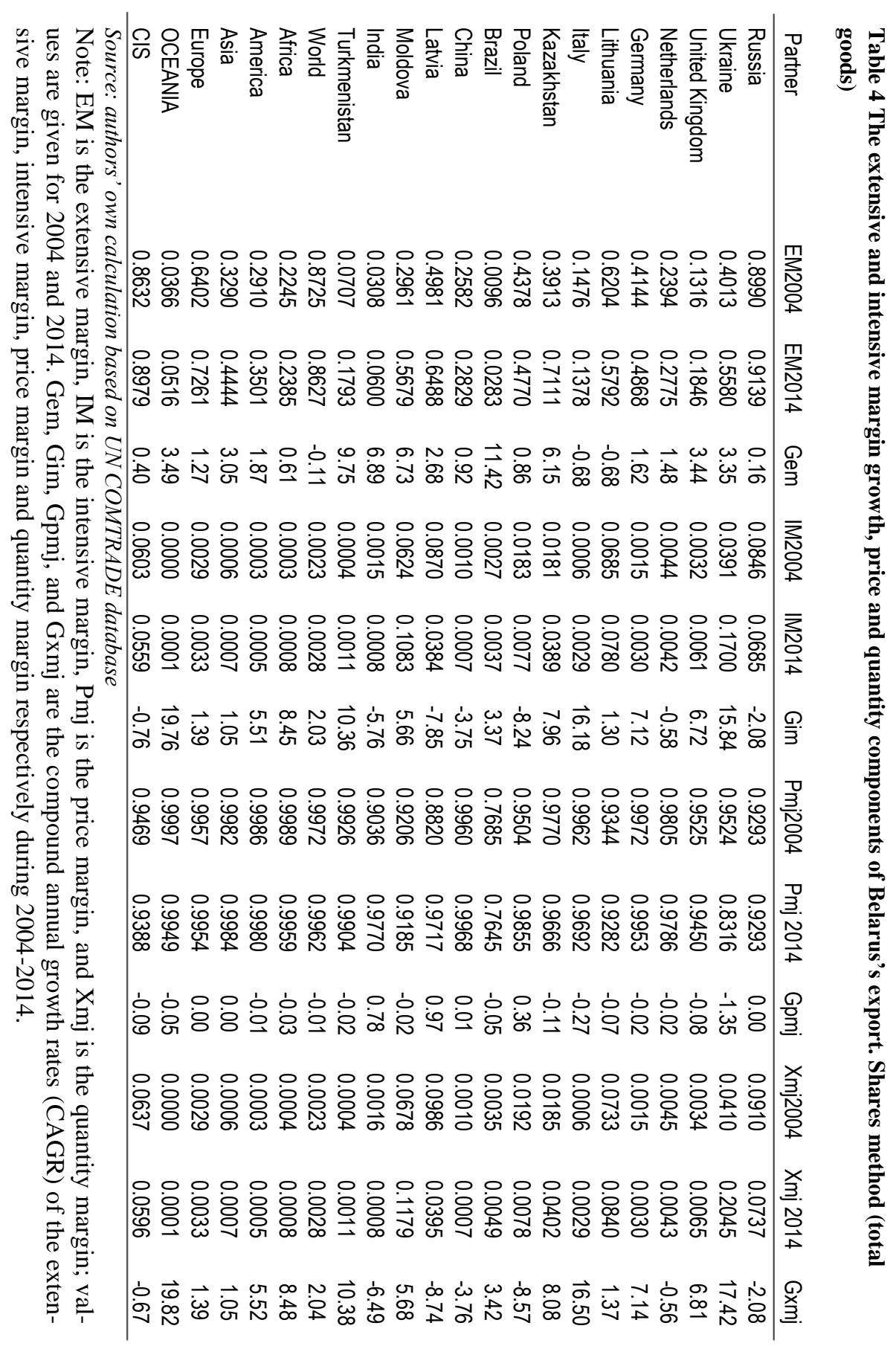




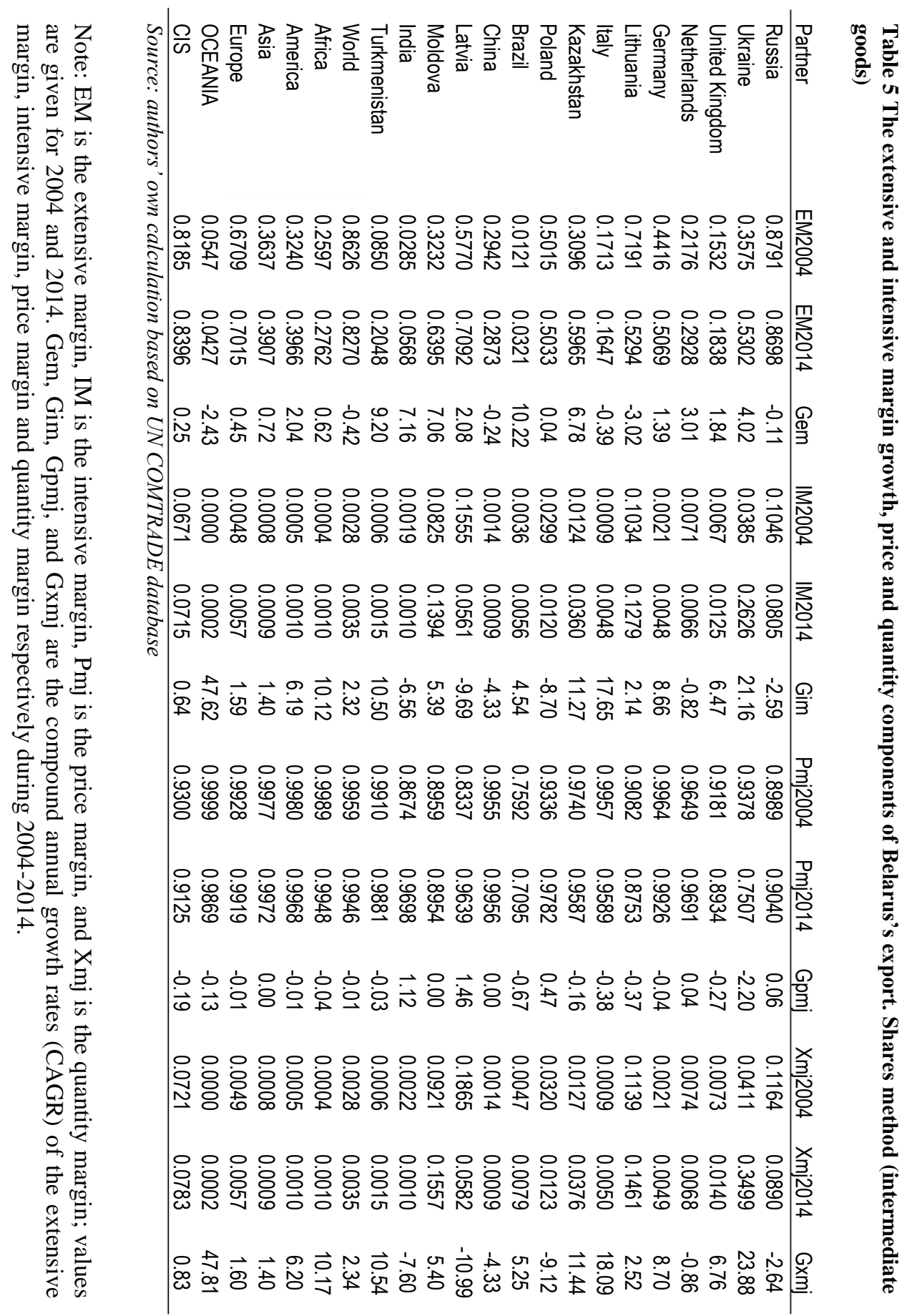




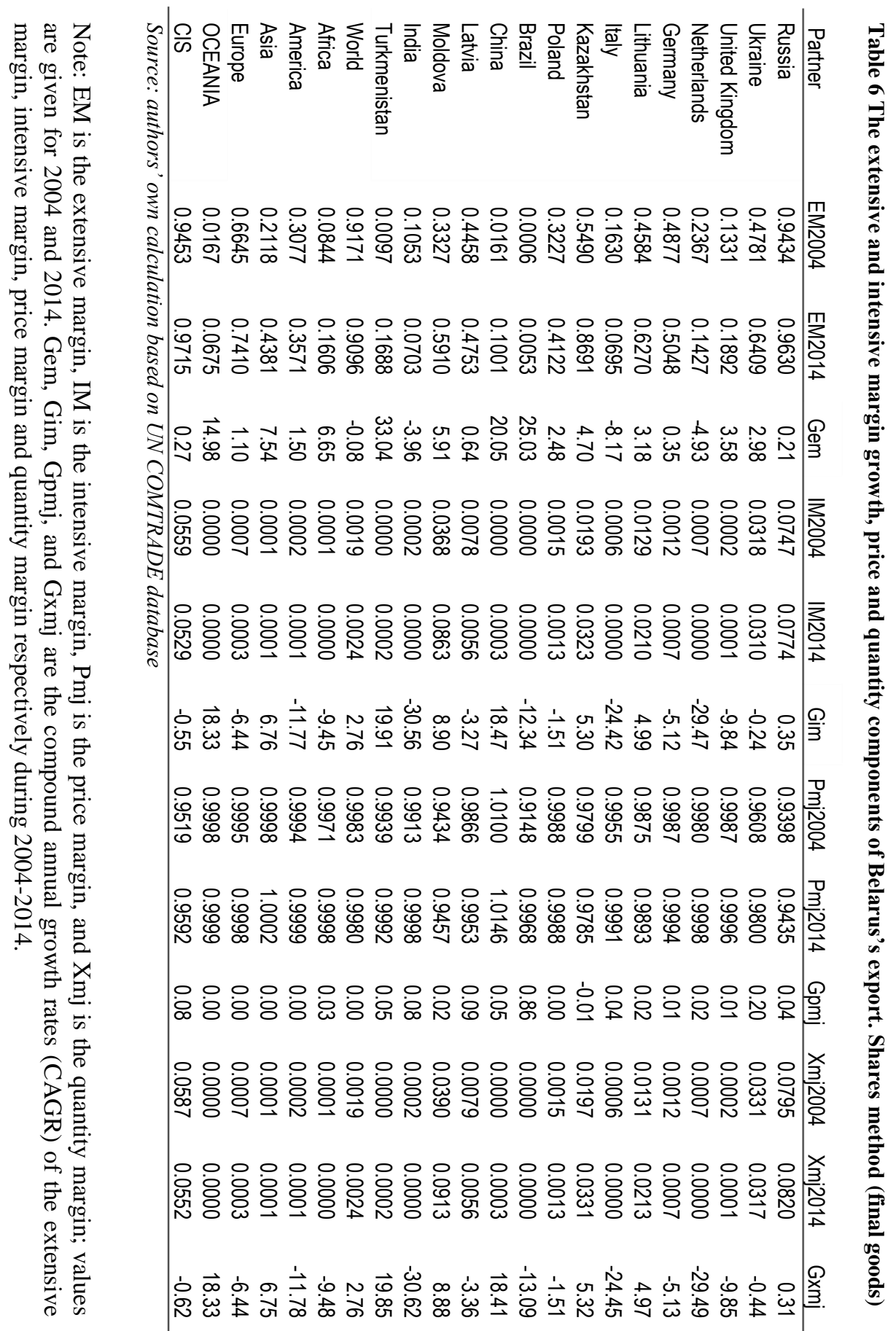

